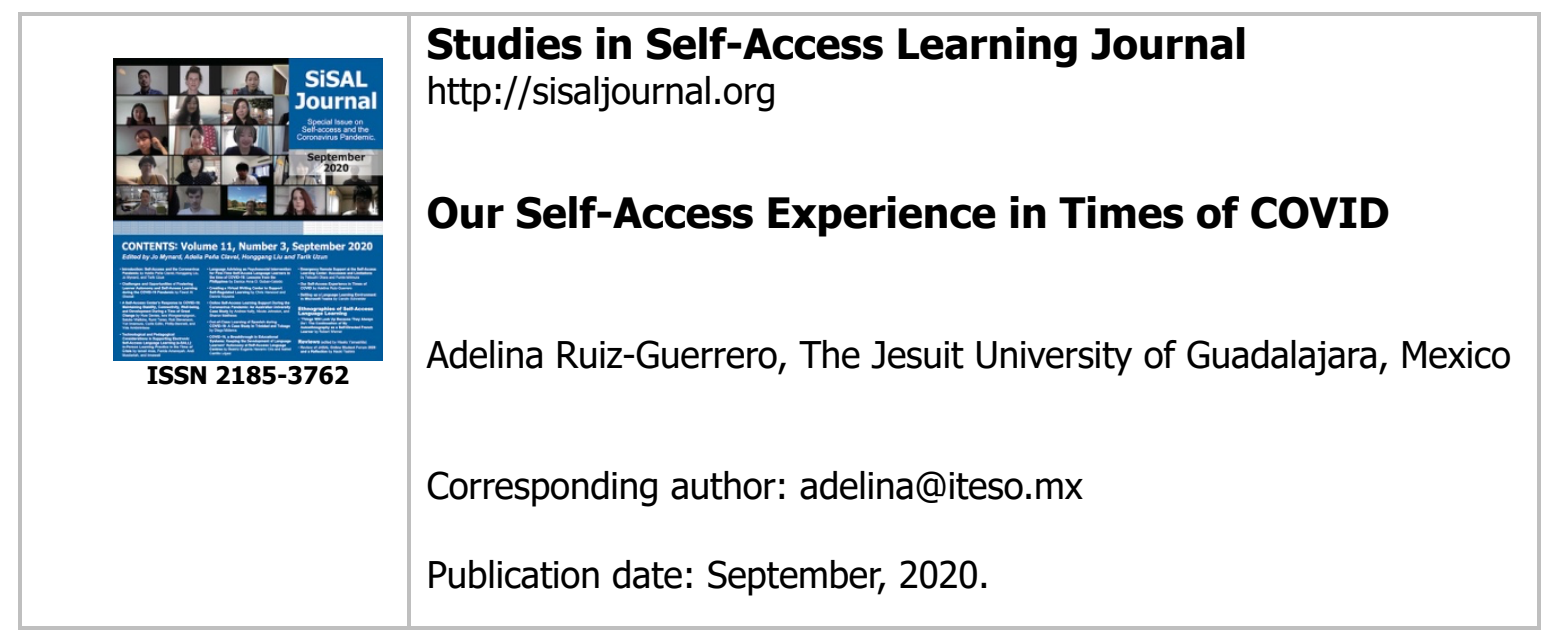

To cite this article

Ruiz-Guerrero, A. (2020). Our self-access experience in times of COVID. Studies in Self-Access Learning Journal, 11(3), 250-262. https://doi.org/10.37237/110311

To link to this article

http://sisaljournal.org/archives/sep20/ruiz-guerrero

This article may be used for research, teaching and private study purposes.

Please contact the author for permission to re-print elsewhere.

Scroll down for article. 
SiSAL Journal Vol. 11, No. 3, September 2020, 250-262.

\title{
Our Self-Access Experience in Times of COVID
}

Adelina Ruiz-Guerrero, The Jesuit University of Guadalajara, Guadalajara, Mexico

\begin{abstract}
The coronavirus pandemic has without a doubt had an enormous impact on every possible way of our lives. We have felt its effects on an individual personal level and as family members, at work, as members of a community, and particularly as students and teachers. Even in institutions and departments such as ours where online education has been at the forefront of our work for years now, the challenge to survive a fully virtual new reality has left us with a lot of lessons learned and has opened doors to more opportunities for growth. For years now, the Language Department at ITESO has had its language courses in LMS platforms and has offered courses in blended and fully virtual options alongside face-to-face classes. In the English Certificate Programme, we have regular teletandem sessions with universities in other countries. The Language Hub, our self-access centre, offers writing support through an emailing writing desk service and we run virtual conversation clubs on Zoom alongside face-to-face sessions. We are certainly no strangers to online work, but up until now, that was just an option both students and teachers could consider. As of March, this year, our whole university had to move to online classes and the services of our self-access centre had to be adapted to virtual options as well. This report presents our answer to the questions posed by SISAL for this open call to the special issue on how we have lived the experience of self-access during the pandemic.
\end{abstract}

Keywords: Self-access, virtual environments, Ignatian Style accompanying, advising, conversation clubs

The Language Hub at ITESO, is a space designed to promote social interactions amongst users. We subscribe to the idea that self-access centres are "social learning environments" (Benson et al., 2016, p. 288) and collaboration between students, advisors, tutors, peer tutors, conversation club hosts and co-hosts, and administrators is a big part of the fabric of the work we do and promote. Although we have offered options of virtual conversation club sessions on Zoom, as well as the e-mailing writing desk service for a few years now, everything else has always been done through face-to-face interactions. We have placed high value on the social interactions that aim to promote and encourage the use of the languages our students are interested in practicing. And although we understood the need for virtual options, they were seen as a "complement" to the services offered. It had been our experience 
SiSAL Journal Vol. 11, No. 3, September 2020, 250-262.

that not all students, and for that matter not all teachers, thrive in virtual environments and so they were maintained as options.

\section{The Language Hub and the Pandemic}

On a regular semester, a variety of options are on permanent offer at the Hub, and they are based out of the physical space on the third floor of the library. One of the most prominent options is the Advising and Tutoring Programme (Programa de Asesorías y Tutorias - PAT) which includes peer tutors (students who can help with English matters or with oral and written communication issues in Spanish), tutors and advisors (for English and for Spanish as a foreign language), on a permanent schedule available at the Hub or by appointment, meeting at the facilities as well. Another popular option is the conversation club. The sessions are usually offered both face-toface at the Hub or virtually via Zoom. There are sessions to practice general English, academic English, Mexican sign language, Japanese and depending on the number and nationalities of the exchange students on campus volunteering to help, French, German, Chinese, and Portuguese. The facilities of the Hub offer spaces designed for collaborative work and opportunities for socializing. There are materials available for use inside the Hub and they may be taken to other areas within the library, but cannot be borrowed for use outside the building. The materials include a wide variety of text books, exam preparation materials, graded readers in different languages and proficiency levels, audio-visual materials including movies, series, and audiobooks. We have an ever-expanding curated section of novels in their original language that include the most popular and sought-after fiction, suspense, drama, fantasy and Young Adult titles available. The Hub facilities include three semiprivate study spaces, 16 computer stations, 10 iPads loaded with a variety of language practice focused apps, and an open work area (see Figure 1).

\section{Figure 1}

The Language Hub, $3^{\text {rd }}$ Floor of the Library

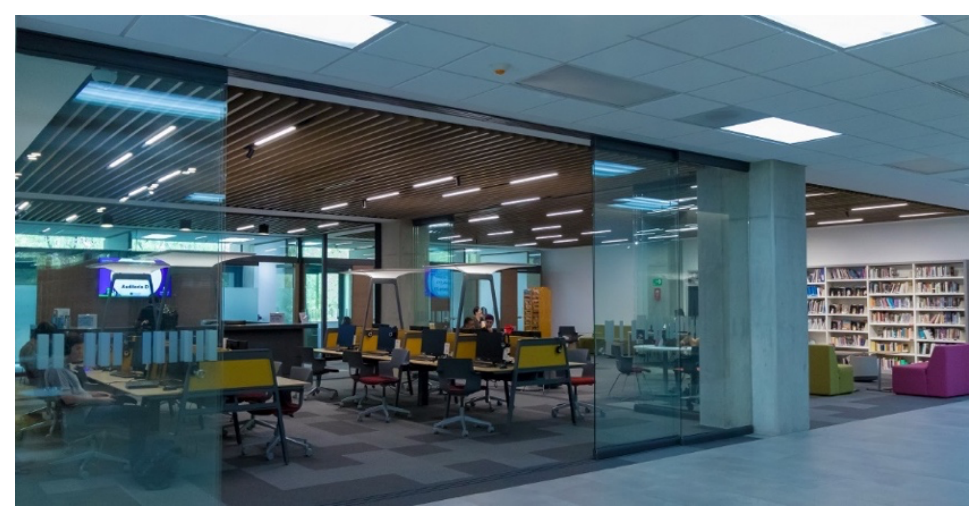


SiSAL Journal Vol. 11, No. 3, September 2020, 250-262.

\section{Aiming High, Especially Under the Pandemic Conditions}

During the contingency established to deal with the pandemic, we managed to not only survive two terms (spring and summer 2020) under these unexpected conditions, but actually see the results in learning and even significant changes in attitude and perceptions towards our own situation. As I read the questions set for this open call for papers that discussed the way self-access centres dealt with the challenges we faced during this contingency, I kept coming to a single possible answer for how we managed to do what we did.

The answer is that we work with a very specific type of leadership and accompanying styles that build community and, I believe that, this is what has allowed us to respond and adapt to the changing situation.

\section{Ignatian Style Leadership}

As a Jesuit institution, we work under the principles of an Ignatian leadership style, what Lowney (2005) calls heroic leadership. This is more than a management style for Jesuit organizations, it is considered part of the fabric of what constitutes the way we interact with each other in our community. It is part of the pedagogical educational model that informs our teaching and the interactions we sustain: students and teachers, teachers and coordinators and in peer relationships at all levels. This leadership style relies on four principles, see Table 1.

\section{Table 1}

Heroic Leadership (Lowney, 2005)

\begin{tabular}{ll}
\hline Self-awareness & $\begin{array}{l}\text { Know self to support others, recognise strengths, } \\
\text { weaknesses and errors } \\
\text { Requires reflection - time and space } \\
\text { It is a constant, ongoing process }\end{array}$ \\
Empathy & Connect, listen, engage, understand, accept, support \\
Belief in the other $\quad \begin{array}{l}\text { Promotor of change } \\
\text { Promote awareness } \\
\text { Provide help }\end{array}$ \\
Aiming high (magis) & $\begin{array}{l}\text { High expectations of yourself and others } \\
\text { Look for the positive, expect the best, believe in the other } \\
\text { Model positive attitude, be your best }\end{array}$
\end{tabular}


SiSAL Journal Vol. 11, No. 3, September 2020, 250-262.

We follow these principles in our everyday work environment, when we interact with learners, and also when we interact with teachers, tutors and advisors. It is through intentional training and by experiencing the modelling of these principles in our daily interactions, we learn to use and internalize them.

So, how did we maintain the social-supportive aspects of self-access? How did we manage to have meaningful interactions with learners using the available technology? How did we overcome the challenges and support learners effectively? And how did we pay attention to the wellbeing of both learners and teachers? We did it by accompanying them and each other.

\section{Ignatian Style Accompanying (ISA)}

As a Jesuit institution, one of our main concerns is the cura personalis, this is the care of the person. We do this in terms of Ignatian style accompanying (ISA) which is a way of supporting a person by walking alongside them (Orozco, 2014). To accompany someone in the Ignatian sense involves: being a good listener, showing empathy through an engaged human connection that enables one to understand the other's situation without any judgement and with an open mind. It requires belief, hope and trust in the other person from a position as equals (Brown \& Clinton, 2020). The ISA principles were of particular relevance during this contingency. More than ever before, the work we all did out of the Hub (tutors, advisors, conversation club hosts and co-hosts, administrators and coordinators) used these principles in every interaction with learners and members of our community to support them, in particular at a personal level.

This accompanying method, when done effectively leads to feeling validated, respected, believed in, taken into account, listened to and motivated (Brown \& Clinton, 2020). It is during these particularly trying times that this kind of support is needed even more. Some of the specific actions that made this accompanying visible during our interventions were, for example, making sure we were approachable not just available, encouraging open dialogue, and promoting and facilitating collaboration. We asked for and accepted opinions and contributions. We made sure to be supportive and encouraging. We recognized achievements and openly admitted what we did not know and asked for help. More importantly, we showed and gave trust. 
SiSAL Journal Vol. 11, No. 3, September 2020, 250-262.

\section{Adjusting to the Pandemic Situation}

Word first came on 13 March that all classes across campus were being transferred to virtual environments. Later, on 20 March we received confirmation that all face-to-face activities were stopping and we were all going to be doing home office and thus closing the doors to the Hub. In light of this, we made a few decisions to cope with the change and support learners to complete the second half of the spring semester as well as possible under the circumstances. We went into quick survival mode by urgently doing the following:

- It was decided that although basic and intermediate level students are required to do Hub visits (one hour a week) as part of their grade (10\%), we would suspend this requirement for the remainder of the semester to remove one source of pressure on the students, teachers and administrators.

- Hub visits that usually included the use of the facilities and the resources physically available in our space, would have only two options: conversation club participation and work with tutors and advisors.

- The writing desk service carried on as usual via email with the option of Zoom conferences if needed.

- Application of exams such as language placement and verification, TOEFL drill, TOEFL ITP, IELTS, was suspended until further notice.

- All face-to-face conversation club options were transferred to Zoom.

- All advising and tutoring schedules were transferred to Zoom and promoted through all institutional means of communication (see Figure 2). 


\section{Figure 2}

Advising and Tutoring Programme. Spring Schedule Offered through Zoom (Adapted for the Contingency).

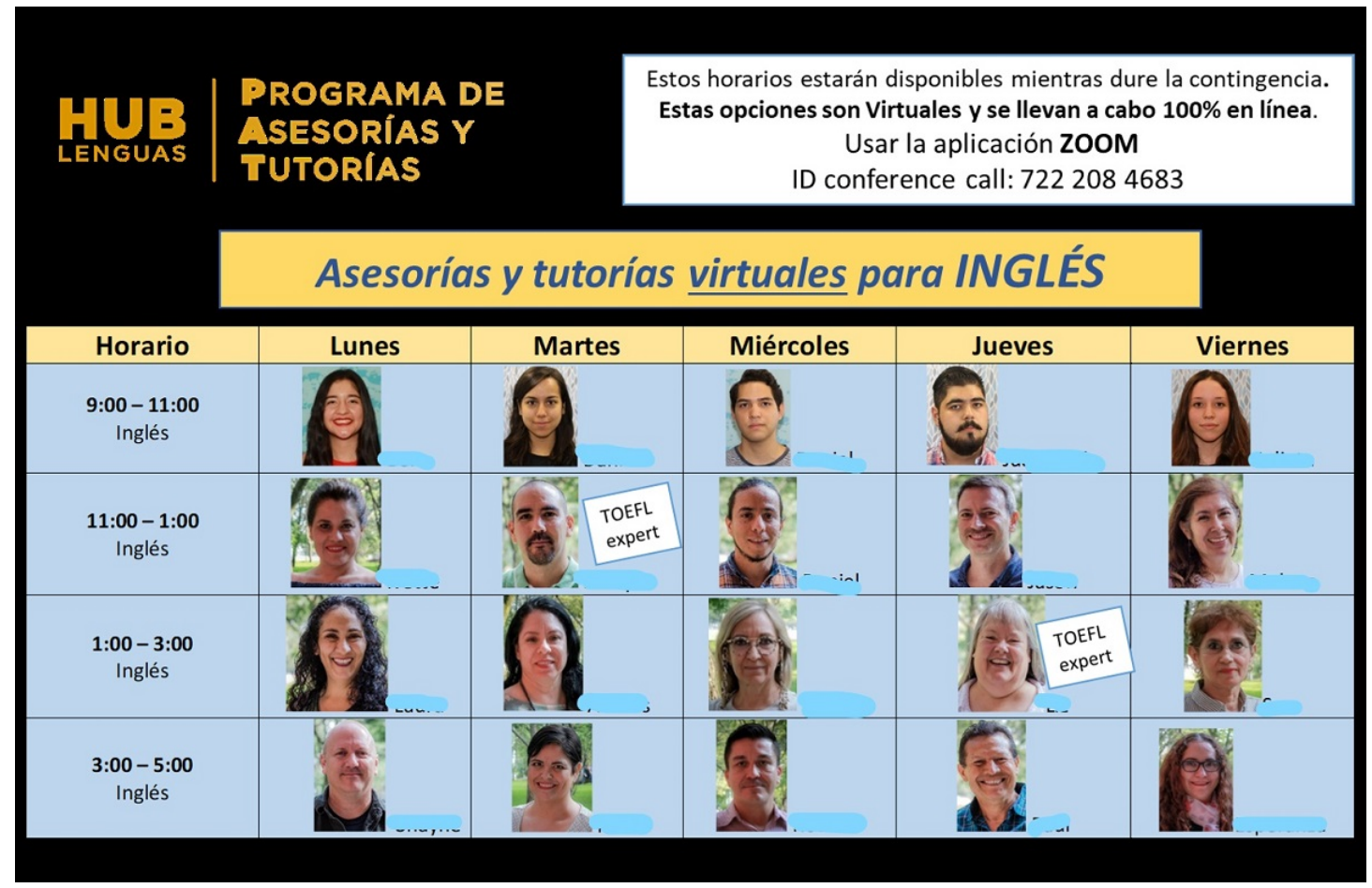

The two main activities that came out of the Language Hub during this contingency were the advising and tutoring programme and the conversation club sessions, as they became our main source of contact with learners. They were the only two activities sanctioned as available towards the official count for Hub visits for students in the English Certificate Programme during the summer and fall terms as the contingency continues. Although we expected registration numbers to go down for the summer term due to the contingency, to our surprise and delight that was not the case. By the end of spring, students already knew summer classes were going to be online again. Registration numbers were actually up from last year, and this allows us to think that even with the stressful situation we experienced during spring, students may have built enough confidence to believe they could do well. It is encouraging to see that students chose to enrol for summer in spite of the forced online option.

Hub visits were up as well, in higher numbers than we were expecting (see Table 2), making us think that the options for social interaction and the type of accompanying we were doing may have been providing more to learners than just opportunities to practice English and they were intentionally and willingly seeking them out. 
SiSAL Journal Vol. 11, No. 3, September 2020, 250-262.

Table 2

Comparison in Attendance Records for Summer Terms 2019 and 2020

\begin{tabular}{rcc}
\hline & $\begin{array}{c}\text { Summer 2019 } \\
\text { Total students } \\
\text { registered: 567 }\end{array}$ & $\begin{array}{c}\text { Summer 2020 } \\
\text { Total students } \\
\text { registered: 623 }\end{array}$ \\
\hline Level 2 & \multicolumn{2}{c}{ Total visits } \\
Level 3 & 208 & 129 \\
Level 4 & 221 & 158 \\
Level 5 & 169 & 186 \\
Level 6 & 295 & 238 \\
Level 7 & 502 & 482 \\
Level 8 & 85 & 386 \\
TOTAL & 153 & 279 \\
\hline
\end{tabular}

From the numbers in the table, we can see that the differences in attendance in the lower levels are not that noteworthy. However, it is important to point out that students in those lower levels do not usually attend virtual options. For this summer 2020 however, they had no other choice and they still maintained their participation levels for the most part. The higher levels, on the other hand are usually less inclined to fulfil the participation quota, but this summer they were the population with the most increased attendance in comparison to last year's summer term.

\section{Lessons Learned from Spring, Applied to Summer}

Once we closed the spring semester, we were able to prepare for the summer term ahead of time, knowing that we would continue working in virtual environments. Having already survived the spring semester, preparing for the summer was easier in many ways and we were optimistic that we could do better. For the summer, we reinstated the Hub visits as part of the grade for students. We started doing some exams online, using Zoom to interact with students. When we were allowed, we started doing on campus applications for the placement exam under controlled conditions and with restricted numbers. Advisors and tutors had to adapt to the changing circumstances and rethink how they were going to be there for learners. In 
SiSAL Journal Vol. 11, No. 3, September 2020, 250-262.

addition, we added more conversation club options to our regular summer schedule to promote as much social interaction as possible.

\section{Advising and Tutoring}

The advising and tutoring programme was based on face-to-face interactions in our self-access centre. Tutors, peer tutors and advisors have time assigned in schedules that make them available to learners for six to eight hours a day in two-hour shifts during a regular term. These schedules were maintained for the duration of the contingency, but the interactions were switched to Zoom videoconferences.

All the resources and materials physically available in the Language Hub are normally part of the options at the disposal of the tutors and advisors, but this was obviously not the case during these past weeks. Tutors and advisors have had to draw upon their personal resources and have also collaborated in giving each other ideas and sharing strategies and tools to make up for not being able to make use of those physical materials such as grammar books, exam preparation texts, exercises and task sheets.

Tutors and advisors reported having done a variety of activities during their Zoom sessions with students. Some of them gave feedback on assignments, helped students with grammar and reading problems or practiced speaking with them. They also facilitated more ludic activities such as games on different platforms: Kahoot, Quizziz, Baamboozle, Scribblio, Pictionary (see Figure 3). They worked on exercises from the course book's online workbook, used the interactive blackboard and shared screens for explanations and practice (see Figure 4). Finally, some reported having shared and discussed PowerPoint presentations, as well as recommended and visited external websites for practice with the students. 
SiSAL Journal Vol. 11, No. 3, September 2020, 250-262.

\section{Figure 3}

Tutoring session: Playing Kahoot on Zoom

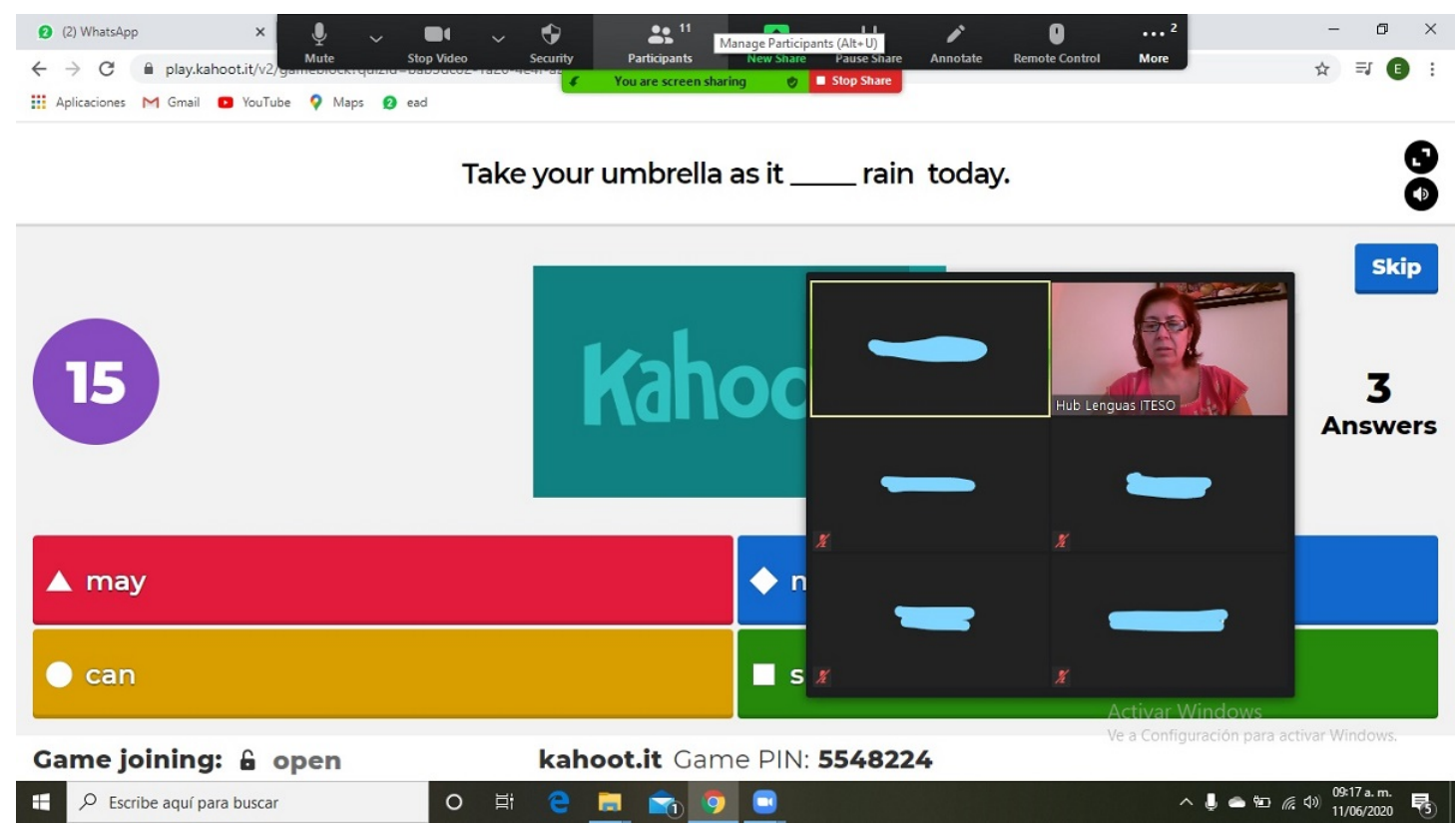

\section{Figure 4}

Tutoring Session: Grammar Explanation, Using PowerPoint and Sharing Screen on Zoom

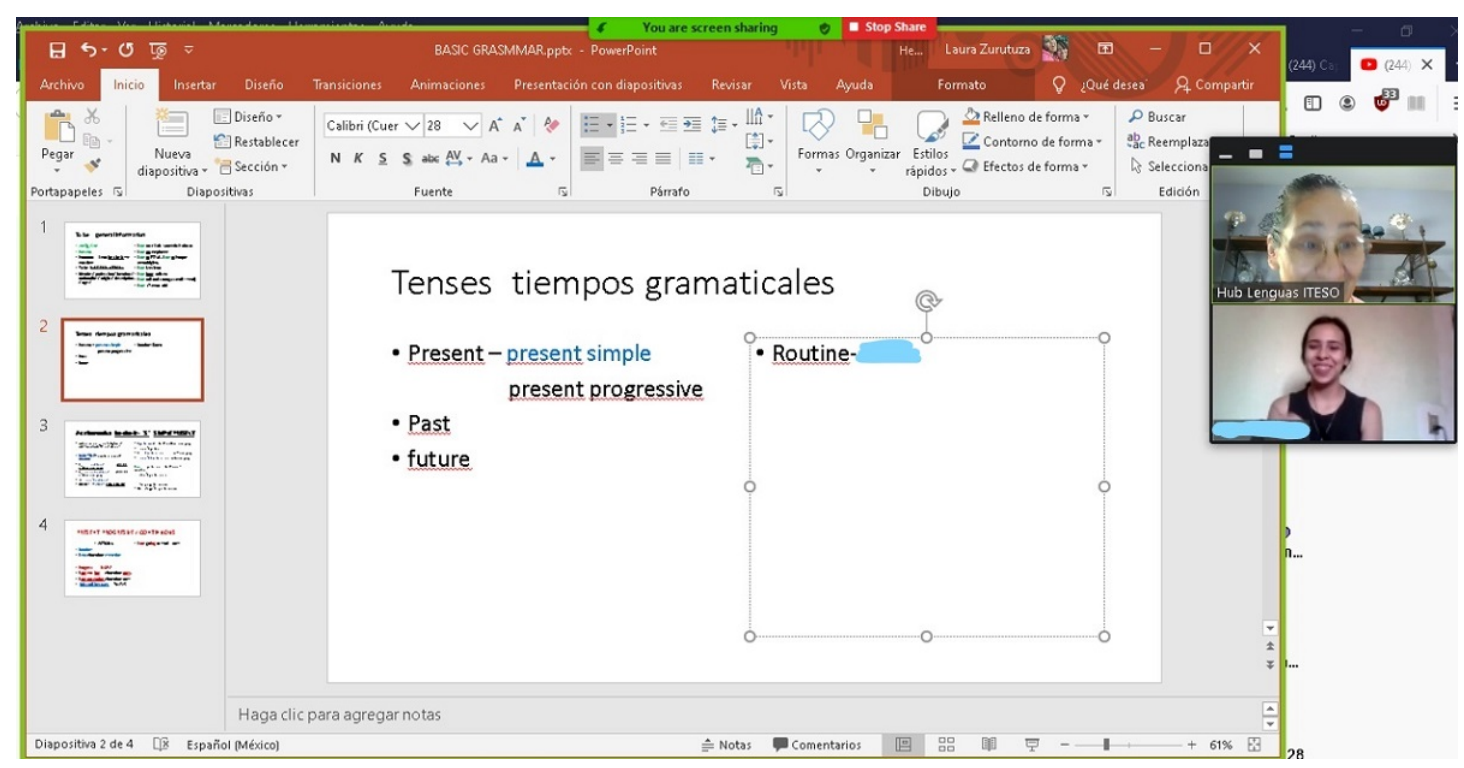

\section{Conversation Club}

For the last few years, the conversation club has had a regular offer of virtual sessions that were regularly and usually used by part-time students who do not have as much time to come to the Hub during our regular service hours. This contingency however, turned all our club sessions into virtual options (see Figure 5) and that 
SiSAL Journal Vol. 11, No. 3, September 2020, 250-262.

brought about certain issues we do not normally have to deal with. For each session we have a host assigned and a co-host on standby in case extra help is needed.

Usually this means that if more than ten people show up to the session, the host calls on the co-host to come in and help with the breakout rooms they create. During the contingency, the number of students showing up to the club sessions increased drastically. This was most likely due to the fact that the Hub visits were limited to only two possible options: either working with a tutor or attending a conversation club session.

\section{Figure 5}

Virtual Conversation Club Sessions: Spring Schedule Offered through Zoom (Adapted for the Contingency)

Club de Conversación - Verano 2020

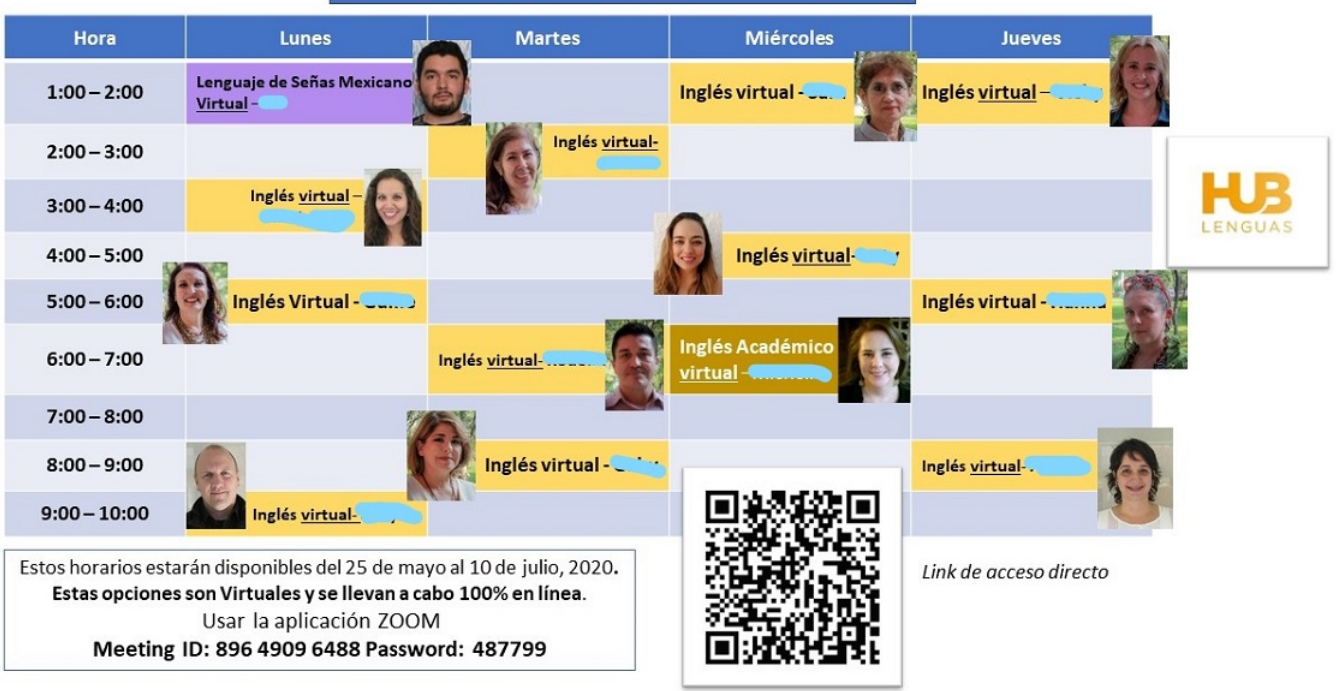

Adapting to the situation meant having to offer three club sessions a day instead of the regular two, having the co-host readily available for high traffic sessions at the end of the week when students who had put off their Hub visit until the last chance available all wanted to attend. Furthermore, we had to set a higher maximum number of participants allowed into the session (we had to go from maximum 20 to 30 ).

During the sessions, the students had the opportunity to discuss a variety of topics and even do activities such as games and the use of Lyrics Training. It was, most important of all, an opportunity to talk to others about the situation we were all 
SiSAL Journal Vol. 11, No. 3, September 2020, 250-262.

going through, share experiences, frustrations, advice, recommendations and, in general, to be in contact. Students reported liking the variety of topics they had the opportunity to discuss, the support they received both from their fellow students and the hosts and co-hosts, meeting new people, the growing confidence they felt at speaking through a camera instead of face-to-face, the chance to hear fellow students with a better level of English and learning from them, and the opportunity to stay in touch with other students.

\section{Conclusion}

This experience has been challenging not only for students, it has also been a trying time for teachers, tutors and advisors, coordinators and administrators alike. We have all had to learn new skills, cope with the stress and uncertainty brought on by the situation, and we have done this while still trying to lead and be there for others. We asked the Hub collaborators (tutors, peer tutors, advisors, club hosts/cohosts, administrators) to recount their experiences and feelings of the past four months and although unfortunately some of them reported negative feelings still after these many weeks into the contingency, the majority spoke of an improved outlook and even a shift into positive attitudes: from having felt frustrated back in March to now feeling accomplished at the end of the summer term, from scared to confident, from vulnerable to comfortable, from stressed to relieved, from apprehensive to reassured.

In general, we all recognize that we have learned a great deal of things:

- how to use more e-tools,

- how to be more flexible and open minded with ourselves and others,

- we have developed more patience,

- we have taught and learned about self-confidence and autonomy, and

- we have certainly grown on a personal and a professional level.

From a coordination position, I have seen us grow as a community where we have learned to listen to each other better and have strived to be there as people and as colleagues for one another. We have formed a strong community of practice (Wenger, 1998) that has allowed us to gather knowledge and experience and solidify bonds that give us identity. We maintained close communication among ourselves, both through formal (institutional email, Teams) and informal (Zoom, WhatsApp, phone calls) channels that allowed us not just to tackle problems but to stay in touch and offer 
SiSAL Journal Vol. 11, No. 3, September 2020, 250-262.

support and friendship. Whenever needed, we collaborated to discuss problems, suggested solutions and reached conclusions. We learned together in formally organized workshops and impromptu teacher-suggested teacher-led sessions (see Figure 6). We still have aspects to improve and processes to streamline, such as coming up with some guidelines for the logistics of virtual tutoring and conversation clubs. Even so, we are optimistic that we have what we need to do a better job.

\section{Figure 6}

Teacher-Suggested Teacher-Led Training Session: Learning How to Use Zoom

\section{Breakout Rooms for the Conversation Club}

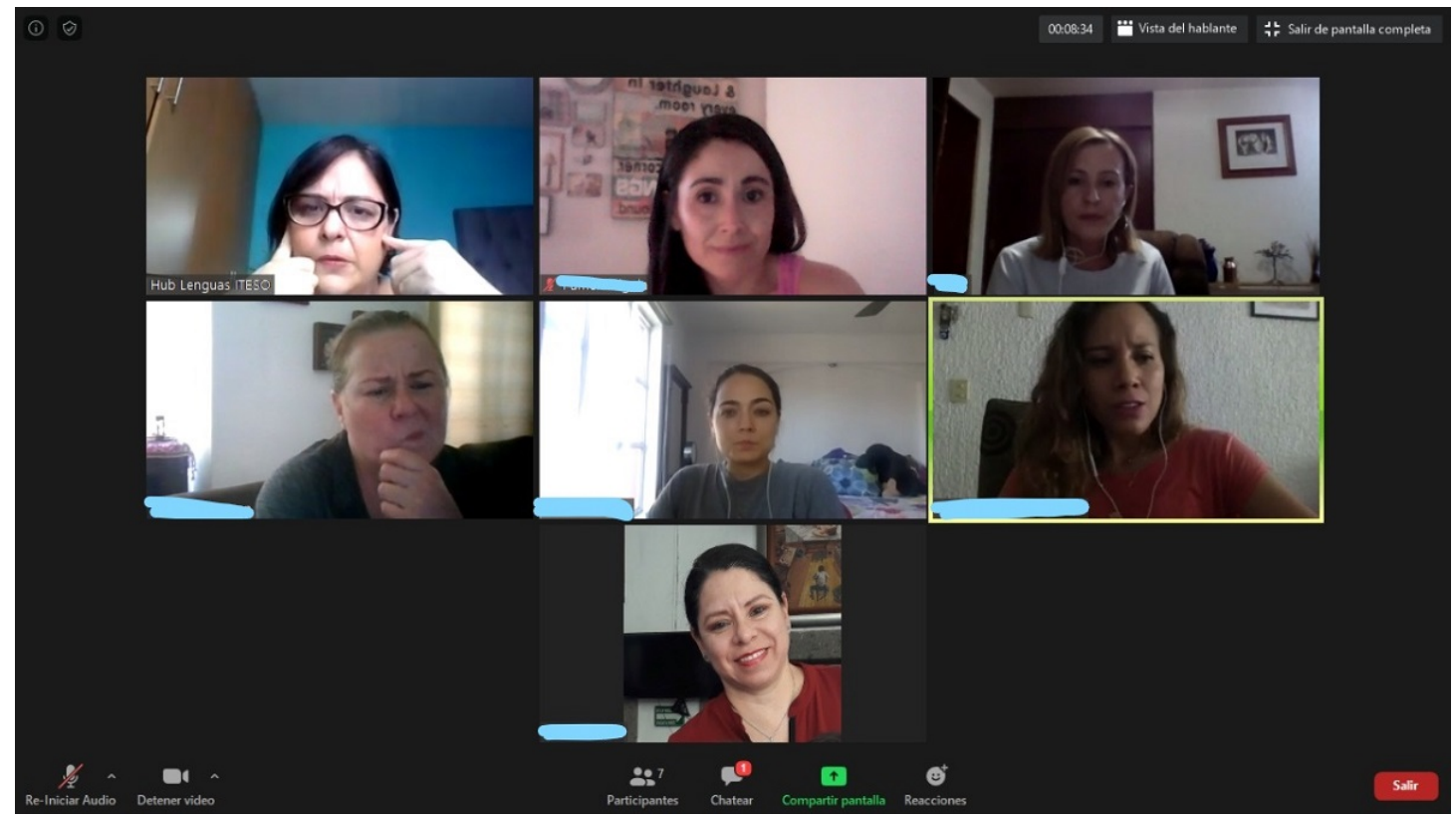

At the time of this submission, we are coming to a well-deserved summer break and the prospect of a virtual fall semester, again. We are certainly better prepared, but we still very much miss the close social interactions that punctuated our daily lives and gave our space its sounds and rhythms, the comings and goings, the changing faces and the feeling of purpose and collaboration. We are stronger, and somehow, in many ways closer in this distance, but it will still feel a lot better to be able to sit at the same table to share coffee, a chat and smiles without face masks while we work in the Hub. Here's hoping for that to come back soon.

\section{Acknowledgements}

All images in this paper were used with permission. 
SiSAL Journal Vol. 11, No. 3, September 2020, 250-262.

\section{Notes on the Contributor}

Adelina Ruiz-Guerrero is Head of the Language HUB (self-access centre) and an academic coordinator in the Language Department at ITESO, The Jesuit University of Guadalajara, in Mexico. Her main research interests are learner and teacher autonomy as well as language learning advising.

\section{References}

Benson, P., Chávez Sánchez, M., McLoughlin, D., Mynard, J., \& Peña Clavel, M. (2016). New scenarios in autonomy for foreign language learning: Conference summary and reflections. Studies in Self-Access Learning Journal, 7(3), 287296. https://doi.org/10.37237/070304

Brown, S., \& Clinton, A. (2020, February 7-8). Accompanying teachers: A road to supporting their professional development [Keynote presentation]. British Council BBELT Conference, Mexico City, Mexico.

Lowney, C. (2005). Heroic leadership, best practices from a 450-year-old company that changed the world. Loyola Press.

Orozco, J. (2014). El cuidado de la persona en el servicio de autoridad al estilo de los Jesuitas [The care of/for the person in the service of authority in the Jesuit style]. ITESO.

Wenger, E. (1998). Communities of practice: Learning, meaning and identity. Cambridge University Press. https://doi.org/10.1017/CBO9780511803932 